\title{
BioLink
}

Jurnal Biologi Lingkungan, Industri, Kesehatan

Available online http://ojs.uma.ac.id/index.php/biolink

\section{EFFECT OF PERIWINKLE (CATHARANTHUS ROSEUS) LEAF EXTRACT ON LIVER HISTOLOGY OF MICE (MUS MUSCULUS L) AFTER ASPARTAME INDUCE}

\author{
Mahriani, Rosita Dewi Wulandari \& Susantin Fajariyah* \\ Department of Biology, Faculty of Mathematics and Natural Sciences, Universitas Jember, \\ Indonesia
}

Submited : 27-04-2021; Reviewed :16-07-2021; Accepted : 08-01-2022

*Corresponding author: E-mail : $\underline{\text { susantin.fmipa@unej.ac.id }}$

\begin{abstract}
Aspartame is an artificial sweetener in foods and beverages. Continuous use of aspartame will result in oxidative stress in the liver. So we need antioxidants from outside the body such as periwinkle leaves. This study aims to determine the effect of periwinkle leaves (Catharanthus roseus $L$ ) on aspartame-induced liver histology. This study used 24 male mice divided into 4 groups, namely negative control ( $K-$ ) without treatment; Positive control $(K+)$ treatment of aspartame; D1: treatment of aspartame and periwinkle extract doses of $0.42 \mathrm{mg} / \mathrm{kg}$. D2: aspartame and periwinkle extract doses of $0.84 \mathrm{mg} / \mathrm{kgbb}$. Administration of aspartame dose of $0.2 \mathrm{mg} / \mathrm{kgbb}$ by intraperitoneal for 14 days followed by gavage administration of periwinkle leaf extract for 12 days. The liver was taken on the 27th day by surgery, then made slide histology with Hematoxylin-Eosin staining. The results shows that the administration of Catharanthus roseus leaf extract at a dose of $0.84 \mathrm{mg} / \mathrm{kgbw}$ in aspartame-induced mice was effective in reducing hepatocyte damage, namely hydrophilic degeneration and necrosis.
\end{abstract}

Keywords: Aspartame; Catharanthus roseus L; Histopathology; Liver

How to Cite: Mahriani, Wulandari, R.D. \& Fajariyah, S. (2022). Effect of Periwinkle (Catharanthus roseus) Leaf Extract on Liver Histology of Mice (Mus musculus L) After Aspartame Induce, BioLink: Jurnal Biologi Lingkungan, Industri dan Kesehatan, Vol. 8 (2): Hal. 125-131 


\section{INTRODUCTION}

Aspartame is an artificial sweetener that is widely used in food and soft drinks such as yogurt, candy and energy drinks (Irawati, 2007). Consumption of artificial sweeteners that exceed the dose of Acceptable Daily Intake (ADI) and consumed continuously can cause negative impacts on body health (Utomo et al, 2012). Aspartame after consumption will undergo metabolism in the body into three compounds, namely aspartic acid, phenylalanine, and methanol (Maulana et al., 2018). Aspartic acid and phenylalanine are amino acids that have an important role for the body (Pertiwi \& Suryani, 2017). Methanol in the body will be oxidized to formaldehyde which is then converted into formic acid (Parthasarathy et al., 2006). Formaldehyde in the body can inhibit the process of cytochrome oxidation in ATP synthesis in mitochondria, then superoxidation of anions and hydroxy free radicals triggers the production of reactive oxygen species (ROS) compounds (Irawati, 2007).

The liver is the largest organ in the human body which has an important role in the processes of metabolism, secretion, synthesis, and detoxification (Muhartono et al., 2019). The role of the liver in detoxification causes the liver to be vulnerable to damage cell structures that can interfere with liver function (Nugraha et al., 2018). Research by Rafwiani \& Suryani (2018) stated that administration of aspartame at a dose of $75 \mathrm{mg} / \mathrm{kg} \mathrm{bw} /$ day for 28 days in male mice caused changes in the histological structure of the mice liver and showed necrosis of hepatocytes.

To repair the damage to the liver caused by free radicals, antioxidants are needed. Antioxidants can be divided into 2 , namely endogenous and exogenous antioxidants. Endogenous antioxidants are produced in the body while exogenous antioxidants are produced and obtained from out of the body such as from plants and food (Werdhasari, 2014). Periwinkle is a plant that contains flavonoid compounds, alkaloids, and quinones that act as antioxidant compounds (Kristanto et al., 2004). Antioxidants can donate electrons to free radicals so that their structure becomes stable so as to protect lipids in cell membranes from experiencing lipid peroxidation (Puspitasari et al., 2016; Dasopang et al., 2021).

Research conducted by Kristanto et al., (2004) stated that the largest antioxidant activity of the Periwinkle plant was found in the leaves, which was $90.27 \%$. Research by Avanapu \& Ahmed (2013) stated that administration of extracts of Catharanthus roseus at doses of $300 \mathrm{mg} / \mathrm{kg}$ bw and $500 \mathrm{mg} / \mathrm{kg}$ bw for 30 days had hepatoprotective activity in simvastatininduced mice. 
Based on this background, it is necessary to conduct research to determine the antioxidant effect of Periwinkle leaf extract on the liver histology of mice induced by aspartame.

\section{MATERIALS AND METHODS \\ Materials}

This study used purple flower palm leaves obtained from the village of Blado Kulon Probolinggo, aspartame, 30 male mice obtained from the Veterinary Center Farma Surabaya, aquadest, ethanol, physiological saline solution, fixative solution (formalin buffer), chloroform, paraffin, Haematoxylin-Eosin dye, entellan, glycerin, xylol.

\section{Preparation Periwinkle Leaf Ethanol Extract}

Periwinkle leaves were obtained from Blado Kulon village, Tegalsiwalan District, Probolinggo Regency. The first step was to wash the palm leaves with clean running water. Then, it was dried in an oven at $50^{\circ} \mathrm{C}$ for 4 days. The dried Periwinkle leaves were mashed with a blender and sieved through a 100 mesh sieve. Periwinkle leaf powder was macerated using $70 \%$ ethanol solution in a ratio of 1:10 for $2 \times 24$ hours. Furthermore, evaporation was carried out with a rotary evaporator at a temperature of $80^{\circ} \mathrm{C}$ to evaporate the solvent (Aisyah, 2018). The results of the extract that obtained will then be concentrated at a temperature of $70^{\circ} \mathrm{C}$ in a water bath to obtain the extract in the form of a paste.

\section{Preparation of test animals}

The test animals used in this study were 24 male mice strain with an average weight of $30 \mathrm{~g}$ obtained from PUSVETMA Surabaya. Mice were placed in cages with paddy husks or sawdust covered with iron wire. Mice were fed and drank aquadest ad libitum. Before being given treatment, the test animals were adapted to laboratory conditions for 1 week.

\section{Treatment on test animals}

This study used 24 male mice divided into 4 groups, namely negative control (K-) without treatment; Positive control $(\mathrm{K}+)$ aspartame treatment only; D1: treatment of aspartame and extract of Periwinkle dose of $0.42 \mathrm{mg} / \mathrm{kgbw}$. D2: treatment of aspartame and extract of Periwinkle dose of $0.84 \mathrm{mg} / \mathrm{kgbw}$. Aspartame exposure at a dose of $0.2 \mathrm{mg} / \mathrm{gbb}$ was carried out intraperitoneally for 14 days followed by gavage treating Periwinkle for 12 days. Mice were killed on day 27 by anesthetized with chloroform. Furthermore, the mice were dissected, the livers were taken and then preparations were made with Hematoxylin-Eosin staining (Aisyah, 2018).

\section{Hepatic Histological Observations}

Histological preparations of the liver were observed using a microscope using 400x magnification in 5 different fields of 
view. Every 1 field of view, 20 cells were counted randomly around the central vein with a total of 100 cells observed in 1 preparation of hepatocytes (Maulida et al., 2013). Observations included the number of hepatocytes that experienced parenchymatous degeneration (cells experienced swelling and turbidity of the cytoplasm), hydropic degeneration (cells looked clear with a cell nucleus in the middle with wide and white hepatocyte cytoplasm), and necrosis (cell nuclei changed in size to a smaller size and condensed).

\section{Data analysis}

The data from the observations of liver histology were statistically analyzed using the Paired Sample T-Test test with a significance level of $0.05 \%$ (Nuryadi et al., 2017).

\section{RESULTS AND DISCUSSION}

The results of the Paired Sample TTest showed that the average amount of hepatocyte damage, namely parenchymatous degeneration, hydrophilic degeneration and necrosis in the aspartame treatment of $0.02 \mathrm{mg} / \mathrm{gbb}$ $(\mathrm{K}+)$ was significantly different from the untreated group (K-) (Table 1). The average number of hepatocyte damage, parenchymatous degeneration, hydropic degeneration, and necrosis in the $\mathrm{K}+$ group was higher than the $\mathrm{K}$ - group. It is presumably because the administration of aspartame in mice can trigger the production of reactive oxygen species (ROS) compounds or free radicals. In these conditions the number of free radicals in the body will increase so that the number is not balanced with the antioxidants produced in the body.

Table 1. Average number of hepatocyte damage in (K-) and (K+) groups

\begin{tabular}{lccc}
\hline \multirow{2}{*}{ Treatment } & \multicolumn{2}{c}{ Average amount of hepatocyte damage \pm SD $\bar{X}$} \\
\cline { 2 - 4 } & $\begin{array}{c}\text { Parenchymatous } \\
\text { degeneration }\end{array}$ & $\begin{array}{c}\text { Hydropic } \\
\text { degeneration }\end{array}$ & Necrosis \\
\hline K- (without aspartame) & $32.33 \pm 6.06$ & $20.50 \pm 2.74$ & $26.00 \pm 4.82$ \\
K+ $(0.02 \mathrm{mg} /$ gbb aspartame) & $40.83 \pm 4.71^{*}$ & $29.83 \pm 5.78^{*}$ & $36.50 \pm 3.89^{*}$ \\
\hline *: there is a significant difference between the treatment groups in the same column
\end{tabular}

Administration of aspartame Rafwiani \& Suryani (2018) stated that the compounds causes changes in cell administration of aspartame at a dose of 75 structure starting from the lightest $\mathrm{mg} / \mathrm{kgbw} /$ day in male mice caused damage, namely parenchymatous changes in the histological structure of the degeneration, hydropic degeneration and liver with necrosis of hepatocytes. the most severe damage, namely necrosis Parenchymatous and hydropic (cell death). The results of the research by degeneration are cell damage that occur as 
a result of structural changes in the form of swelling. Swelling of cells occurs because the cells are unable to maintain the electrolyte balance of $\mathrm{Na}+$ and $\mathrm{K}+$ ions inside and outside the cell (Dewi \& Saraswati, 2009). Necrosis is irreversible cell damage, meaning that cell damage cannot return to normal cells and cells will die (Maulida et al., 2013). Hepatocytes that have been damaged by necrosis cannot be recovered by antioxidants so that the cells will undergo karyolysis (Kasno, 2008).

The results of the Paired Sample TTest on hepatocyte damage in mice treated with Periwinkle extract after being induced by aspartame can be seen in Table 2 . The average number of hepatocytes with hydrophilic degeneration and necrosis was significantly different compared to $\mathrm{K}+$ in both D1 and D2. Meanwhile, hepatocytes with parenchymatous degeneration were not significantly different from $\mathrm{K}+$ in either D1 or D2. It is presumably because the administration of Periwinkle leaf extract can reduce the average damage to hydrophilic degeneration hepatocytes that prevent necrosis. Research conducted by Avanapu \& Ahmed (2013) stated that treating Periwinkle leaf extract at doses of $300 \mathrm{mg} / \mathrm{kg}$ and $500 \mathrm{mg} / \mathrm{kg}$ in mice could provide significant hepatoprotective activity.

Table 2. Average number of hepatocytes that were damaged by administration of Periwinkle leaf extract in aspartame-induced mice

\begin{tabular}{|c|c|c|c|}
\hline \multirow[t]{2}{*}{ Treatment } & \multicolumn{3}{|c|}{$\begin{array}{l}\text { Average amount of hepatocyte damage } \\
\qquad \bar{X} \pm \text { SD }\end{array}$} \\
\hline & $\begin{array}{c}\text { Parenchymatous } \\
\text { degeneration }\end{array}$ & $\begin{array}{c}\text { Hydropic } \\
\text { degeneration }\end{array}$ & Necrosis \\
\hline $\mathrm{K}+(0.02 \mathrm{mg} / \mathrm{gbb}$ aspartame $)$ & $40.83 \pm 4.71$ & $29.83 \pm 5.78$ & $36.50 \pm 3.89$ \\
\hline $\begin{array}{l}\text { D1 (aspartame } 0.02 \mathrm{mg} / \mathrm{gbb}+\text { tapak dara leaf } \\
\quad \text { extract } 0.42 \mathrm{mg} / \mathrm{kgbb} \text { ) }\end{array}$ & $38.67 \pm 7.59$ & $27.50 \pm 4.32^{*}$ & $30.17 \pm 6.01^{*}$ \\
\hline $\begin{array}{l}\text { D2 (aspartame } 0.02 \mathrm{mg} / \mathrm{gbb}+\text { tapak dara leaf } \\
\text { extract } 0.84 \mathrm{mg} / \mathrm{kgbb} \text { ) }\end{array}$ & $35.83 \pm 2.32$ & $24.00 \pm 4.47^{*}$ & $30.67 \pm 3.61^{*}$ \\
\hline
\end{tabular}

*: there is a significant difference between the treatment group and $\mathrm{K}+$ in the same column

Periwinkle is a plant that has the radical reactions. Flavonoid antioxidants potential to produce antioxidant can prevent the formation of free radicals compounds (Kristanto et al., 2004). The by donating their $\mathrm{OH}$ groups to free radical greatest antioxidant potential, in the compounds and breaking free radical chain Periwinkle plant was found in the leaves of reactions, thus forming stable compounds. $90.27 \%$. One of the compounds present in It can reduce the amount of damage to the tapak dara plant is flavonoid tissue cells due to free radical activity compounds (Hariana, 2008). Flavonoids are （Puspitasari et al., 2016). compounds that are able to protect lipids in cell membranes against damaging free 


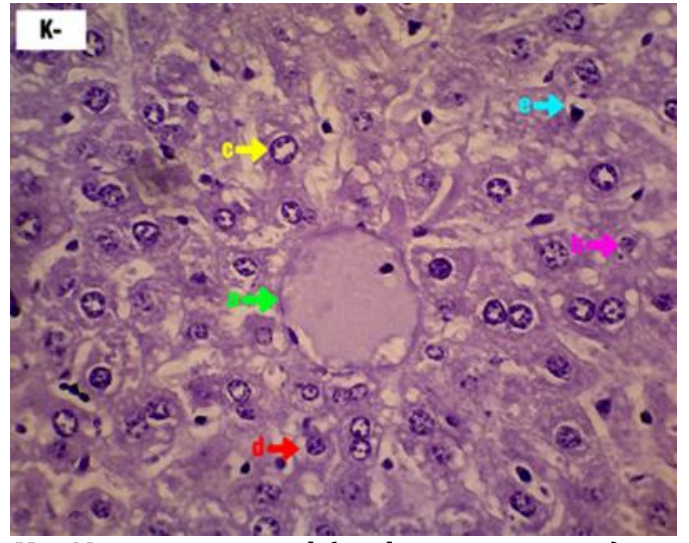

K- : Negative control (without treatment)

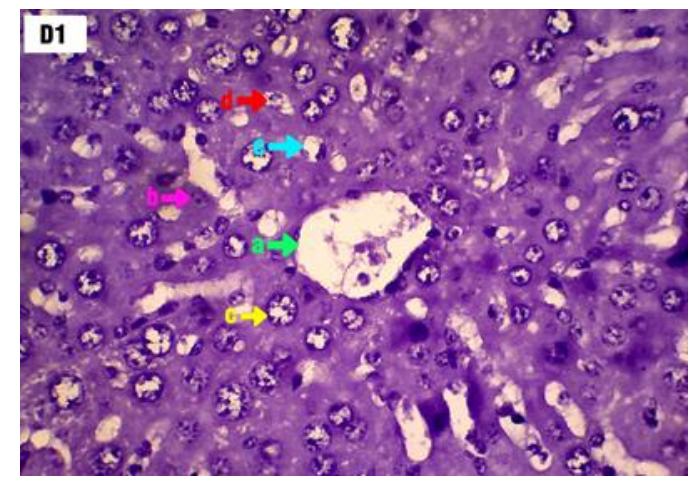

D1: Aspartame $0.02 \mathrm{mg} / \mathrm{gbb}$ continued Periwinkle leaf extract $0.42 \mathrm{mg} / \mathrm{kgbb}$

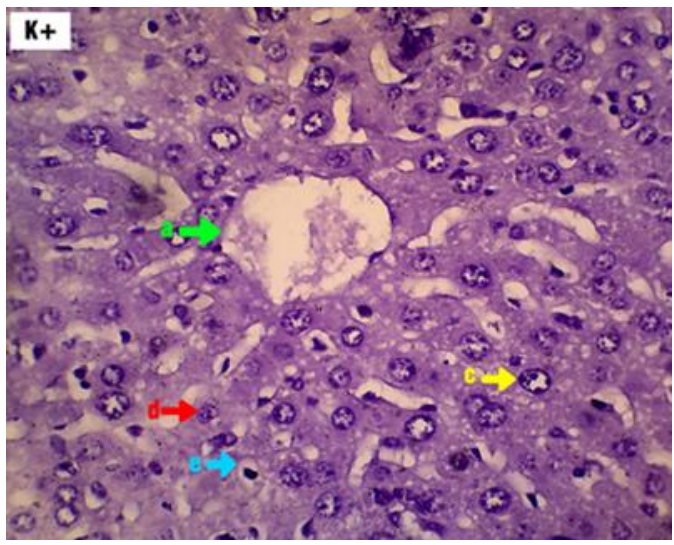

$\mathrm{K}+$ : Positive Control (aspartame $0.02 \mathrm{mg} / \mathrm{gbb}$ )

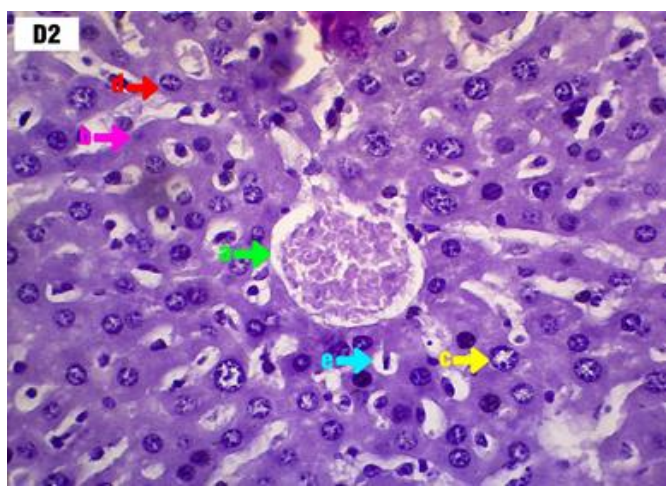

D2: Aspartame $0.02 \mathrm{mg} / \mathrm{gbb}$ continued Periwinkle leaf extract $0.84 \mathrm{mg} / \mathrm{kgbb}$

Figure 1. Histology of the liver of mice (Mus musculus L.) after aspartame induction and administration of Periwinkle leaf extract, with HE staining and 400x magnification.

\section{CONCLUSION}

Administration

of

Periwinkle

(Catharanthus roseus) leaf extract of a dose

of $0.84 \mathrm{mg} / \mathrm{kg}$ for 12 days in aspartame-

induced mice was effective in reducing

hepatocyte damage, namely hydrophilic

degeneration and necrosis.

\section{REFERENCES}

Aisyah, S. N. (2018). Histopatologi hepar mencit (Mus musculus) strain Balb/C setelah pemberian ekstrak etanol daun tapak dara (Catharanthus roseus) (Skripsi) Jember: Fakultas Matematika dan Ilmu Pengetahuan Alam Universitas Jember.

Astuti, S. (2008). Isoflvon kedelai dan potensinya sebagai penangkap radikal bebas. Jurnal
Teknologi Industri dan Hasil Pertanian. 13(2) : 126-137.

Avanapu, S. R, \& Ahmed, M.F. (2013). Phytochemical evaluation and hepatoprotective activity of Catharanthus rosea against sivastatin-induced hepatotoxicity in rats. International journalof advances in pharmacy medicine and bioallie sciences. $1:$ :-12

Dasopang, E. S., Nasution, J., Suharyanto, A., Chandra, R. H., \& Pratama, I. (2021). Hispathology And Effectiveness Of Wound Healing Cream Karo Oil Herbal Extract On Male Mice In North Sumatra, Indonesia. NVEO-NATURAL VOLATILES \& ESSENTIAL OILS Journal| NVEO, 2769-2777.

Dewi, U. K. \& Saraswati, T.R. (2009). Efek rebusan daun tapak dara pada dosis dan frekuensi yang berbeda terhadap kerusakan dan akumulasi glikogen pada hepar mencit (Mus musculus). BIOMA. 11(1):1-5.

Hariana A. (2008). Tanaman Obat dan Khasiatnya Seri III. Jakarta (ID): Penebar Swadaya.

Irawati, U. B. (2007). Pengaruh aspartam terhadap kadar kreatinin serum dan struktur histologi 
ren mencit (Mus musculus L.) strain Swiss (Skripsi) Surakarta: Fakultas Matematika dan Ilmu Pengetahuan Alam Universitas Sebelas Maret.

Kasno, P. A. (2008). Patologi Hati dan Saluran Empedu Ekstra Hepatik. Semarang : Balai Penerbit Universitas Diponegoro.

Kristanto, A., W. A. Mustaqim., E. Suhartono., dan N. Qamariah. 2004. Skrining tanaman obat yang berpotensi sebagai antioksidan in vitro. Mutiara Medika. 4(1) : 5-11.

Mahdi, C \& Aulaniam. (2011). Suplementasi yogurt pada tikus (Rattus norvegicus) yang terpapar formaldehid dalam makanan terhadap aktivitas antioksidan enzimatis jaringan hepar. NATURAL B. 1(2): 183-187.

Maulana, A. M., A. G. Perdana, R. Soesilowati, M. F. Romdhoni, dan R. A. N. Putra. (2018). Pengaruh aspartam terhadap struktur histologi hepar tikus (Rattus norvegicus) jantan galur wistar model diabetes melitus. Ibnu Sina Biomedika. 2(1) : 1-7.

Maulida, A., S. Ilyas dan S. Hutahaean. (2013). Pengaruh pemberian vitamin $\mathrm{c}$ dan e terhadap gambaran histologis hepar mencit (Mus musculus L.) yang dipajankan monosodium glutamat (MSG). Saintia Biologi. 1(2) : 15-20.

Muhartono., R. Z. Oktarlina dan N. S. Purohita. (2019). Pengaruh pemberian minuman ringan berkarbonasi terhadap gambaran histopatologi hepar tikus putih (Rattus norvegicus) jantan galur Sprague Dawley. Medical Journal. 8(1) : 71-77.
Nugraha, A. P., S. Isdadiyanto dan S. Tana. (2018). Histopatologi hepar tikus wistar (Rattus norvegicus) jantan setelah pemberian teh kombucha konsentrasi 100\% dengan waktu fermentasi yang berbeda. Buletin Anatomi dan Fisiologi. 3(1) : 71-79.

Nuryadi, T.D. Astuti, E.S. Utami dan M. Budiantara. (2017). Dasar-Dasar Statistik Penelitian. Yogyakarta: Biomedika.

Parthasarathy, J. N., Ramasundaram, S. K., Sundaramahalingam, M. and S. D. Pathinasamy. (2006). Methanol induced oxidative stress in rat lymphoid organs. J. Occup. Health 48, 20-27.

Pertiwi, R. \& Suryani. D. (2017). Pengaruh pemberian minuman berenergi yang mengandung aspartam terhadap nilai fungsi ginjal tikus jantan (Rattus norvegicus L.). Buletin Farmatera. 2(1) : 47-54.

Puspitasari, M. L., T. V. Wulansari, T. D. Widyaningsih, J. M. Maligan dan N. I. P. Nugrahini. (2016). Aktivitas antioksidan suplemen herbal daun sirsak (Annona muricata L.) dan kulit manggis (Garcinia mangostana L.). Jurnal Pangan dan Agroindustri. 4(1) : 283-290.

Utomo, Y., A. Hidayat., M. Dafip dan F. A. Sasi. (2012). Studi histopatologi hati mencit (Mus muscuus L.) yang diinduksi pemanis buatan. Jurnal MIPA. 35(2) : 1224-129.

Werdhasari, A. (2014). Peran antioksidan bagi kesehatan. Jurnal Biotek Medisiana Indonesia. 3(2) : 59-68. 